Agricultural Water Management, Volume 96, Issue 2, February 2009, Pages 226-232

\title{
Irrigation management practices of cabbage farmers in Botswana using saline groundwater.
}

\author{
T. M. Hess ${ }^{1} \&$ G. Molatakgosi ${ }^{2}$ \\ ${ }^{1}$ School of Applied Sciences, Cranfield University, Bedford, MK43 OAL, UK. Tel. +44 1234 \\ 750111. email t.hess@cranfield.ac.uk. Corresponding author. \\ ${ }^{2}$ Department of Agricultural Research, Ministry of Agriculture, Private Bag 0033, Gaborone, \\ Botswana. Tel. +267328780
}

\begin{abstract}
All horticultural production in Botswana is irrigated, as average rainfall is less than average reference evapotranspiration in all parts of the country for all of the year, and most of the irrigation in the country is used for horticultural crops. In the main, the water used for irrigation comes from groundwater, and much of this can be classified as moderately saline. A survey was carried out of 60 cabbage farmers in 5 regions of the country to identify the level of salinity of irrigation water and the irrigation practices used. It was concluded that there was no relationship between the irrigation rate (average irrigation depth divided by average irrigation interval) and the salinity of the water used or the salinity of the soil, such that some farmers were over-irrigating and others under-irrigating. This means that water is being wasted and yields are likely to be reduced. In addition, there is a risk of long-term build-up of salinity and soil degradation.
\end{abstract}

Keywords: Irrigation; scheduling; salinity; cabbage; Botswana.

\section{Introduction}

Botswana is a landlocked country located between $18-27^{\circ} \mathrm{S}$ and $20-30^{\circ} \mathrm{E}$ in southern Africa with an average elevation of $1000 \mathrm{~m}$ above sea level. The climate is semi-arid with a cool dry season between May and September and a hot wet season between October and April. The average annual precipitation of $450 \mathrm{~mm}$ is unreliable and unpredictable, whilst the average annual reference evapotranspiration is $1400 \mathrm{~mm}$ and exceeds average precipitation in every month (FAO, 1984).

About $85 \%$ of the land is covered by the Kalahari sands and shrub savannah with the driest region towards the south characterised by active sand dunes and very sparse vegetation. Water resources are extremely scarce in many parts of the country. The potential of using surface water for irrigation development in Botswana is limited as all the rivers within the country are either dammed, or planned for damming, for domestic water use or livestock watering. In 2002, only 1439 ha were irrigated, of which only 620 ha were irrigated in the dry season (FAO, 2005).

Almost all irrigation is for horticultural crops (FAO, 2005) - mainly varieties of brassica, tomatoes (Lycopersicon esculentum) and onions (Allium cepa) - and irrigation is essential for vegetable cropping (Bok et al., 2003). Most irrigation uses groundwater from deep (>10 m below ground level) aquifers (Department of Water Affairs, Pers. Com.) with poor recharge and moderate levels of salinity (Tahal Consulting Engineers, 2000). The country has the potential to produce $75 \%$ of its national demand of horticultural produce but produces only $20 \%$ (Tahal Consulting Engineers, 2000).

Cabbage (Brassica oleracea var. capitata) is grown in two cropping seasons. A crop may be planted between March and May so that it grows through the winter months (May to August) and a summer crop may be planted between October and 
November. Most that grow cabbage also grow other vegetables alongside or in rotation.

Cabbage is moderately sensitive to the salinity of irrigation water. Ayers and Westcot (1985) suggest a threshold electrical conductivity of irrigation water, $\mathrm{EC}_{\mathrm{w}}$, of $1.2 \mathrm{dS}$ $\mathrm{m}^{-1}$ for maximum yield and Beltrão et al., (2000) found that yields decreased linearly

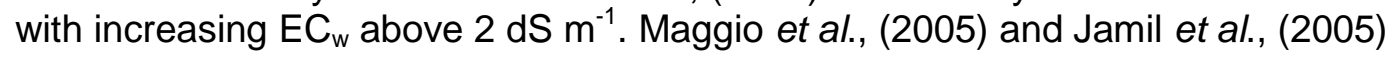
both observed significant reductions in head fresh weight with irrigation water with an $\mathrm{EC}_{\mathrm{w}}$ around $4 \mathrm{dS} \mathrm{m}^{-1}$ associated with reduced leaf area and above ground dry matter.

If salts added to the soil through irrigation water are not adequately leached, the level of soil salinity will gradually increase. The salinity of the soil is usually expressed as the electrical conductivity of the saturation extract, $\mathrm{EC}_{e}$, and Maas and Grattan (1999) suggest a threshold value of $1.8 \mathrm{dS} \mathrm{m}^{-1}$ for maximum yield of cabbage. Above this threshold, head fresh weight was estimated to decline at a rate of $9.7 \% / \mathrm{dS} \mathrm{m}^{-1}$ (Maas and Grattan, 1999).

In Botswana, rainfall is insufficient to leach salts from the soil profile. For sustainable production, additional irrigation water over and above the crop water requirements should be applied according to the salinity of the irrigation water in order to avoid excessive accumulation of salts in the soil (Maas and Grattan, 1999). FAO and Ministry of Agriculture (1998) concluded that inadequate investigation and / or poor design has resulted in inefficient operation and the use of saline water in some irrigation schemes. Many farmers have limited irrigation management experience and are poorly informed about irrigated agriculture. This paper reports on a survey of cabbage farmers in Botswana that aimed to identify whether, and how, cabbage farmers in Botswana adapt their irrigation management according to the salinity of the water used.

\section{Methodology}

\section{Climate}

Climate data from Gaborone, Jwaneng, Mahalapye, Francistown and Maun were used to represent the climate of each region (Table 1). Average monthly reference evapotranspiration, ETo, was calculated from average monthly met data from the FAO CLIMWAT database with the Penman-Monteith method, except for Jwaneng, where average monthly maximum and minimum temperatures were used with the Hargreaves method for reference evapotranspiration, calibrated against the other four stations (see Allen et al., (1998) for methods). The crop water requirement of cabbage at full ground cover, ETc, was estimated using assuming a crop coefficient of 1.05 (Allen et al., 1998). 


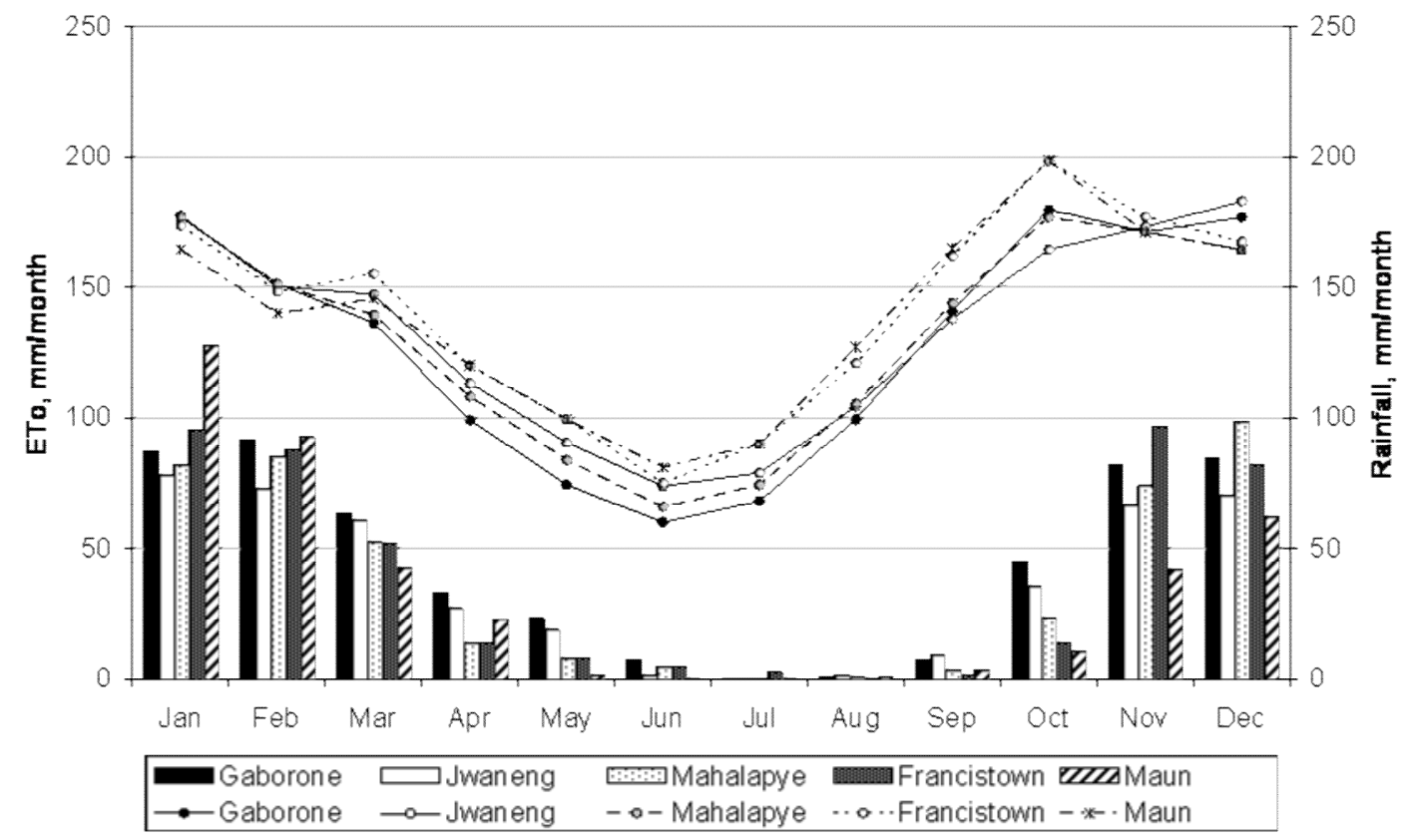

Figure 1 Average (1989 - 2002) monthly rainfall and reference evapotranspiration (ETo) for five stations in Botswana.

\section{Farmer survey}

An on-farm survey was conducted between June and September 2004 in five of the six agricultural regions of the country. The farmers selected all grew cabbage using irrigation water drawn from boreholes. Information was collected on;

1) Farm identity; name, size, location, years of operation.

2) Crop; crops grown, depth and methods of cultivation, area allocated to cabbage.

3) Irrigation; method, duration and interval.

4) Soil and water salinity; Electrical conductivity of irrigation water, $\mathrm{EC}_{\mathrm{w}}$ and root zone soil water, $\mathrm{EC}_{\mathrm{s}}$. Farmers' perception of the salinity.

\section{Irrigation practices}

The typical application rate and depth applied was assessed in the field according to the irrigation system used.

Hand irrigation refers to a system whereby farmers apply water using portable containers (e.g. watering cans, buckets). The depth of water applied was estimated from the volume of the container used for irrigation, the area of the bed and the number of containers applied at each irrigation.

Where the farmer was using a number of sprinklers on a lateral, five catch-cans were placed at equal intervals (of at most $3 \mathrm{~m}$ ) depending on the sprinkler spacing, between two sprinklers. The catch-cans were left until each one of them had collected at least $50 \mathrm{ml}$. The volume of water collected in each can and the time taken were recorded.

Where the farmer was using a single sprinkler and moving it around, the radius of the wetted circle was measured. Five catch-cans were placed at equal intervals in the direction of the sprinkler move from the sprinkler to the end of the wetted soil. The cans were left in place and the sprinkler moved as normal until the sprinkler had past 
all the cans and no more water was collected in any one of them. The volume and taken to collect the water in each can was recorded.

Where the farmers were using drip irrigation, catch-cans were placed under the first and last emitters of the first, middle and the last laterals. Cans were left to stand until the amount of water collected was at least $50 \mathrm{ml}$. The time taken to collect the water was noted and the irrigation depth at each irrigation was estimated.

In order to compare irrigation systems, the average irrigation rate was estimated as the amount of water applied at each irrigation divided by the average interval between irrigations.

\section{Soil and water salinity}

$\mathrm{EC}_{\mathrm{w}}$ was measured using a portable conductivity meter. For hand irrigation, water was collected from the water source whereas for drip and sprinkler irrigation, the water collected in the catch-cans was tested.

Three different positions in the field were chosen for soil sampling. The first position was within the plant row, the second one between the rows and the last one at the edge of the cropped area. At each position, a hole was dug to $0.5 \mathrm{~m}$ (estimated as the effective rooting depth). Soil samples were taken at the soil surface, $0.12,0.25$, 0.37 , and $0.5 \mathrm{~m}$ below the soil surface. About $300 \mathrm{~g}$ of soil from each depth was collected in a sampling bag. The soil textural class was identified by feel.

The soil samples were taken to the laboratory, a saturation extract prepared (U.S. Salinity Laboratory Staff, 1954) and $\mathrm{EC}_{\mathrm{e}}$ was measured using a conductivity meter.

\section{Statistical analysis}

All attribute data analysed in the project was tested using the chi-square test. Unless otherwise stated, all the measurement data was analysed using the Duncan multiple range test (DMRT), and all the error bars in the figures represent the range of $95 \%$ confidence interval. All tests were done at the alpha level of 0.05 .

\section{Results}

\section{Climate}

Average long term (1989 - 2002) monthly rainfall and reference evapotranspiration are shown in Table 1. All the regions are characterised by a summer rainy season from October to March and a dry winter. At all the stations, average precipitation is lower than average reference evapotranspiration throughout the year (Figure 1). 
Table 1 Number of farmers, dates during which each agricultural region was visited for interview and average climate for five agricultural regions in Botswana.

\begin{tabular}{|c|c|c|c|c|c|c|c|c|}
\hline \multirow[t]{2}{*}{$\begin{array}{c}\text { Agricultural } \\
\text { Region }\end{array}$} & \multirow[t]{2}{*}{$\begin{array}{c}\text { Dates } \\
\text { of } \\
\text { Visit } \\
(2004)\end{array}$} & \multirow[t]{2}{*}{$\begin{array}{c}\text { No. } \\
\text { Farmers }\end{array}$} & \multicolumn{3}{|c|}{ Met Station } & \multicolumn{2}{|c|}{$\begin{array}{c}\text { Annual } \\
\text { rainfall } \\
(1989 \text { - } \\
\text { 2002) }\end{array}$} & \multirow{2}{*}{$\begin{array}{c}\text { Annual } \\
\text { ETo } \\
\text { Mean, } \\
\text { mm }\end{array}$} \\
\hline & & & Name & Location & $\begin{array}{c}\text { Alt, } \\
\text { m }\end{array}$ & $\begin{array}{c}\text { Mean, } \\
\mathrm{mm}\end{array}$ & $\begin{array}{l}\mathbf{C V} \\
\%\end{array}$ & \\
\hline Gaborone & $\begin{array}{l}14- \\
26 / 6\end{array}$ & 10 & Gaborone & $\begin{array}{l}24.40^{\circ} \mathrm{S} \\
25.55^{\circ} \mathrm{E}\end{array}$ & 994 & 525.7 & $36 \%$ & 1536.6 \\
\hline Southern & $\begin{array}{c}5- \\
10 / 7\end{array}$ & 10 & Jwaneng & $\begin{array}{l}24.60^{\circ} \mathrm{S}, \\
24.66^{\circ} \mathrm{E}\end{array}$ & 1189 & 443.5 & $34 \%$ & 1593.6 \\
\hline Central & $\begin{array}{c}2- \\
14 / 8\end{array}$ & 20 & Mahalapye & $\begin{array}{l}23.05^{\circ} \mathrm{S}, \\
28.48^{\circ} \mathrm{E}\end{array}$ & 1006 & 448.2 & $29 \%$ & 1567.1 \\
\hline Francistown & $\begin{array}{l}16- \\
21 / 8\end{array}$ & 10 & Francistown & $\begin{array}{l}21.13^{\circ} \mathrm{S}, \\
27.30^{\circ} \mathrm{E}\end{array}$ & 1000 & 459.5 & $40 \%$ & 1689.8 \\
\hline North West & $\begin{array}{c}6- \\
11 / 9\end{array}$ & 10 & Maun & $\begin{array}{l}19.59^{\circ} \mathrm{S} \\
23.25^{\circ} \mathrm{E}\end{array}$ & 994 & 407.5 & $33 \%$ & 1671.8 \\
\hline
\end{tabular}

\section{Cabbage cropping}

In all regions, most farmers were growing cabbage in the winter and only $18 \%$ of the farmers interviewed also grew cabbage in the summer. $85 \%$ of the farmers had been growing cabbage for five years or less. With an average farm size of 2.8 ha (ranging from 0.1 ha to $30 \mathrm{ha}$ ), the area of farm land planted with cabbage varied from 0.006 ha to 5 ha with an average of 0.66 ha per farm. Soil texture varied from clay to sand and there was no significant difference between the soil type used for growing cabbage in the different regions.

All the farmers interviewed produced crops using only light cultivation and none were using mulch after the crops were transplanted. No farm had a subsurface drainage system.

\section{Irrigation systems}

The irrigation systems used varied significantly between the regions. In Gaborone, North West and Southern Regions, more farmers used sprinklers whereas in Francistown Region and Central Region hand irrigation and drip irrigation respectively were most common (Figure 2). 


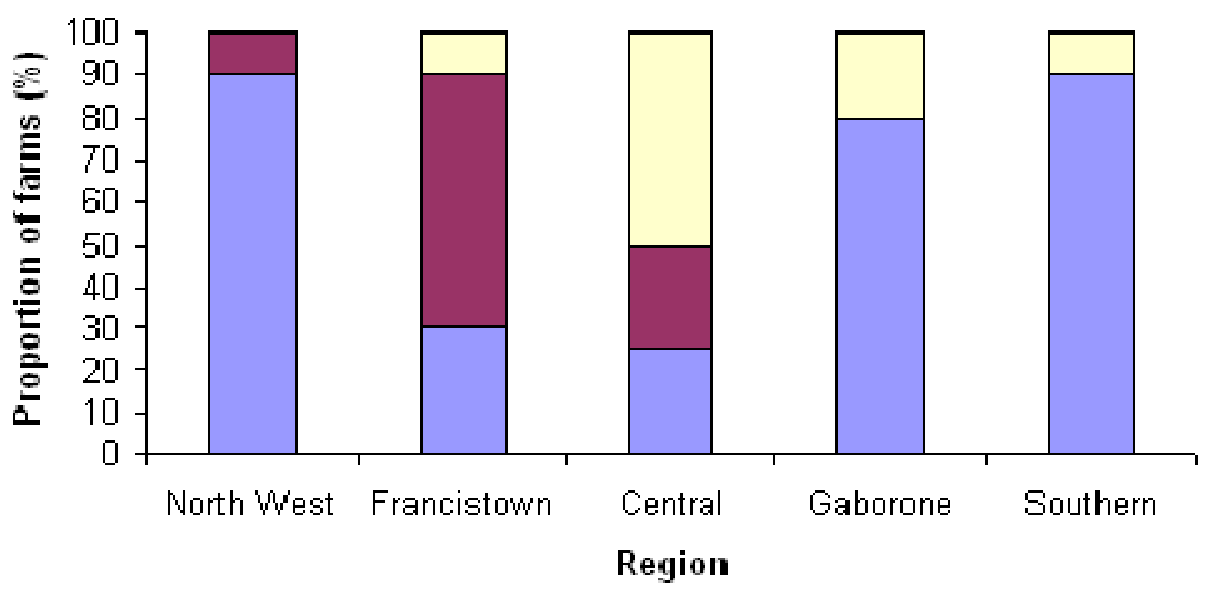

$\square$ Sprinkler irrigation $\square$ Hand irrigation $\square$ Drip irrigation

Figure 2 Proportion of farms using different irrigation systems in each region.

\section{Irrigation management}

Farmers based their irrigation scheduling on observation of the soil or crops. They did not schedule irrigation independently for the different crops they grew and they irrigated different crops with the same irrigation depth and interval. Only $22 \%$ of the farmers changed their irrigation schedule between growing seasons.

The average irrigation interval was 3 days (range $1-7$ days) and the average application depth was $13 \mathrm{~mm}$ (range $3-45 \mathrm{~mm}$ ) (Figure 3). On average, farmers using sprinklers used larger applications $(p=<0.001)$ and longer intervals $(p=$ $<0.001$ ) than those using drip irrigation. The applications and intervals used by those irrigating by hand were not significantly different from those using the other two methods (Figure 4).

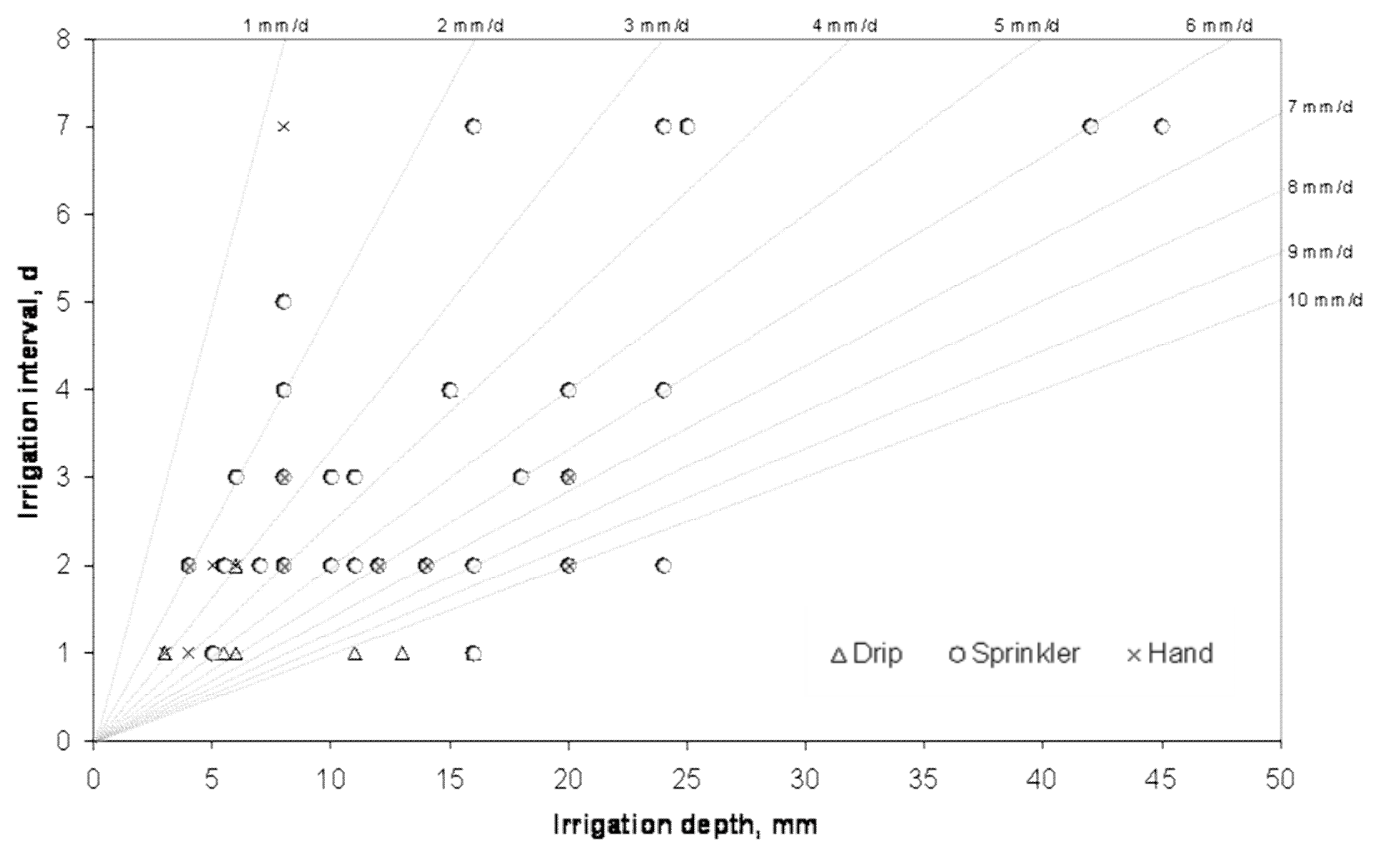

Figure 3 Irrigation depth and interval for different irrigation methods. 


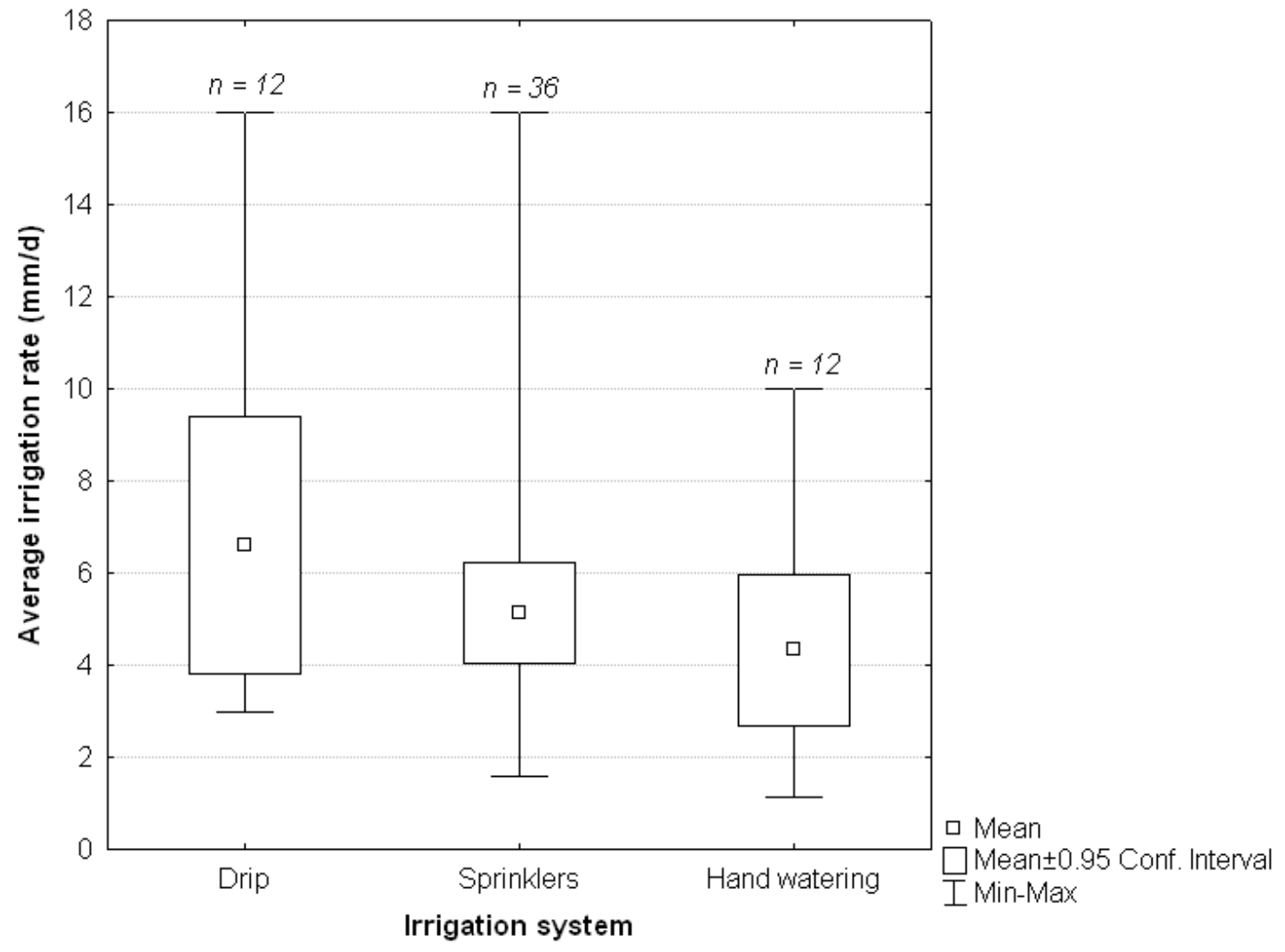

Figure 4 Average application depth $(\mathrm{mm} / \mathrm{d})$ by irrigation system for cabbage farmers in Botswana.

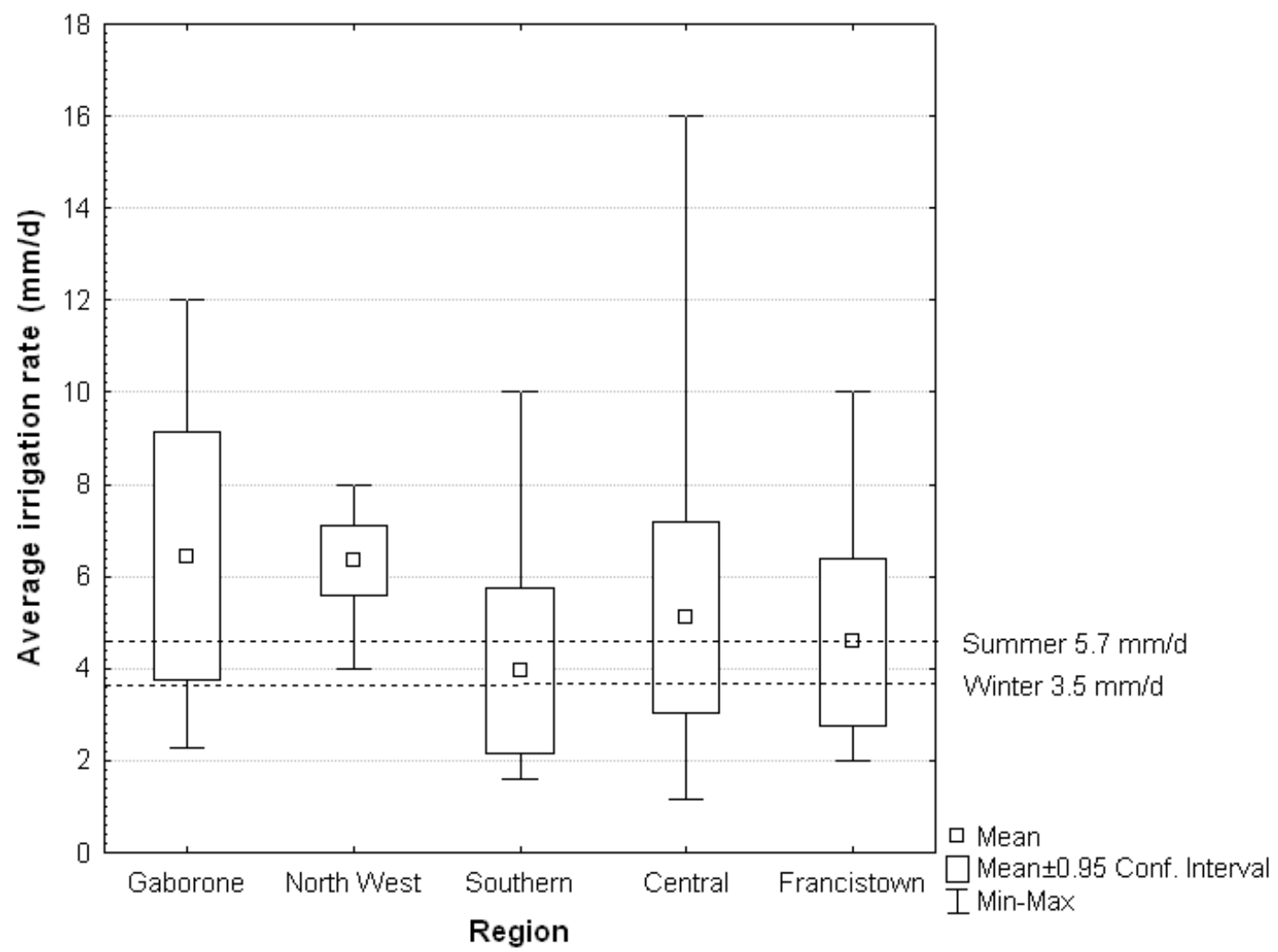

Figure 5 Average application depth and average summer and winter crop evapotranspiration (ETc) in five agricultural regions of Botswana. 
On average, the cabbage farmers surveyed were irrigating at an average of $5.3 \mathrm{~mm} / \mathrm{d}$ and there was no significant difference in the average application rates between irrigation systems (Figure 4) or region (Figure 5).

\section{Soil and water salinity}

There was no significant difference in irrigation water salinity between the regions (Figure 6). Although most of the farmers said that they knew the salinity status of their water, none of them had done any scientific test - they estimated the salinity status either by tasting the water or observing white deposits on the soil. Most of the farmers in Central Region believed that the water they used for irrigation was salty whereas in Southern and in North West Regions most farmers believed that it was not. In the Gaborone Region, most farmers said that they did not know the salt status of their irrigation water. Figure 7 shows that most farmers did not have a good understanding of the salinity status of the irrigation water. The average $\mathrm{EC}_{\mathrm{w}}$ of the 23 farmers who believed that they had saline water is only slightly higher than that of the 29 farmers who believed that their water was not saline. However the large ranges on Figure 7 suggest that many farmers had an incorrect perception of their water status. None of the farmers who believed that their water was salty was doing anything about it.

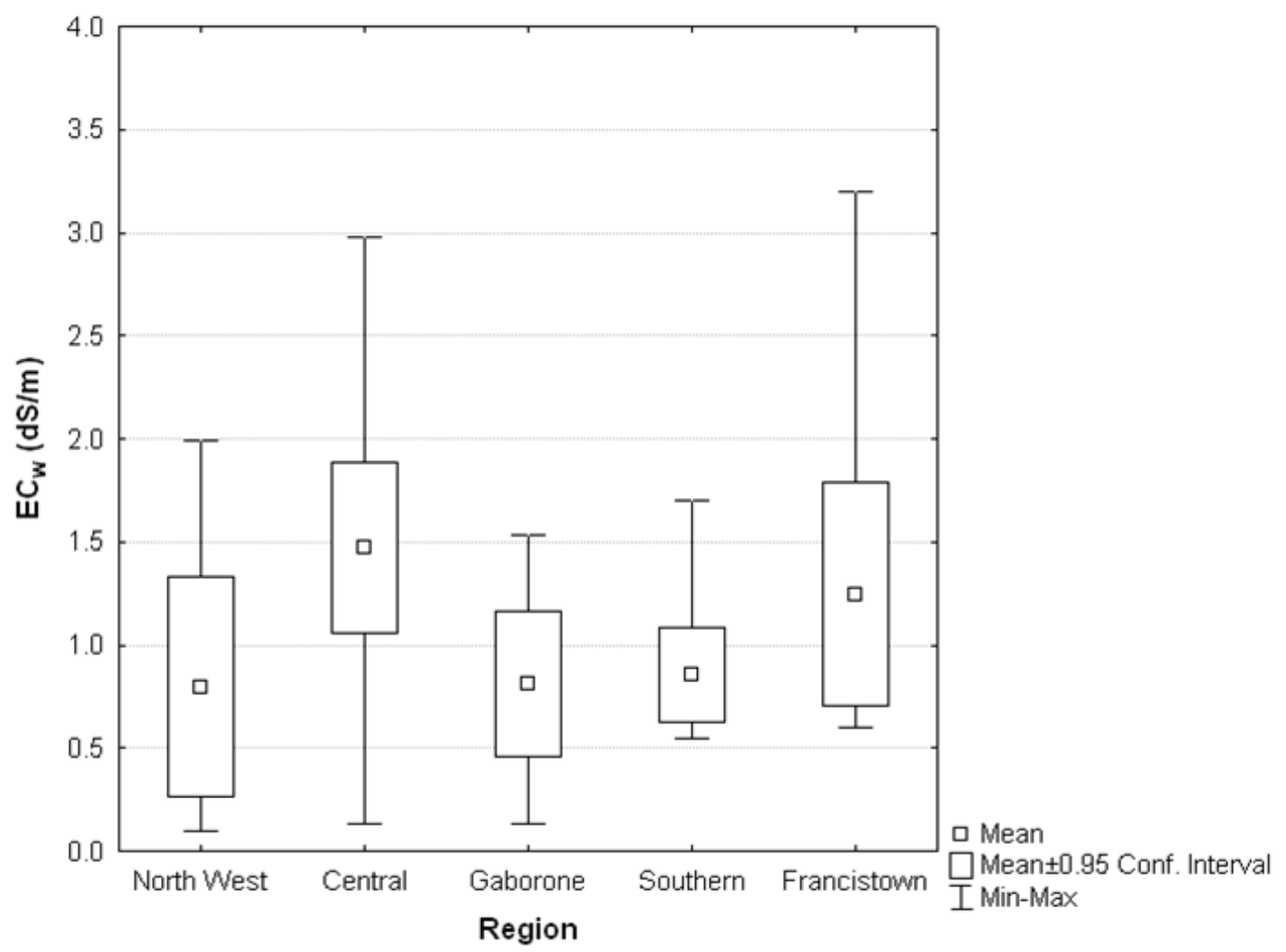

Figure 6 Average irrigation water salinity for five regions in Botswana. 


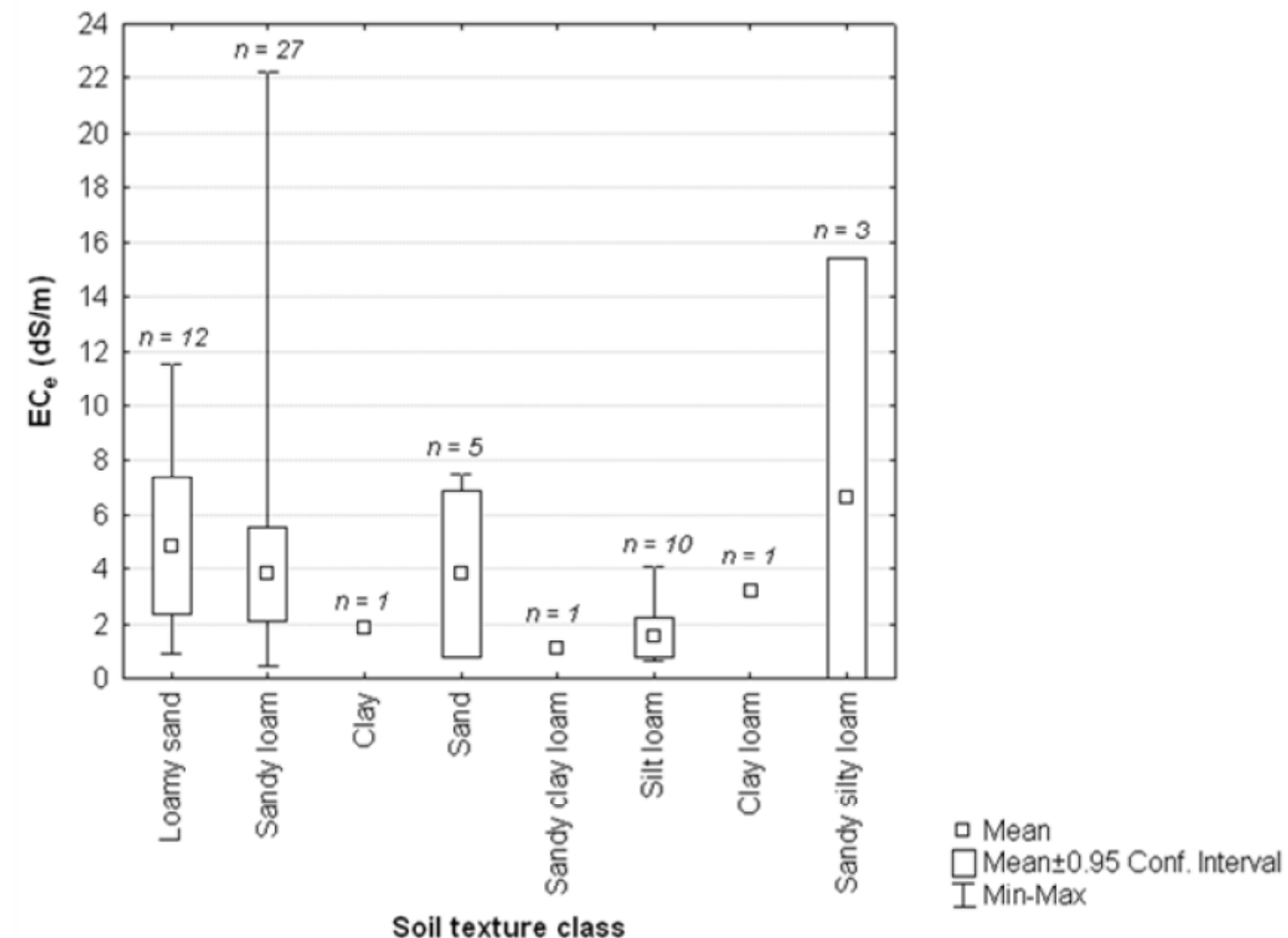

Figure 7 Actual irrigation water salinity for the farmers' perception groups.

The average $E_{e}$ was $3.7 \mathrm{dS} \mathrm{m}^{-1}$ and was significantly $(\mathrm{p}<0.001)$ higher in the Central Region ( $6.3 \mathrm{dS} \mathrm{m}^{-1}$ ) than Francistown, Gaborone and Southern Regions (Figure 8). There was no significant difference in root zone salinity between the soil types (Figure 9). From Figure 10, it is clear that most of the farmers did not know the salinity status of their soil. Only 4 farmers believed that their soil was saline but there was no significant difference in average soil salinity between the groups. As with irrigation water, those who believed that their soil was salty, said that they were doing nothing about it. There was no significant relationship between the amount of irrigation water applied per day and the electrical conductivity of the soil water extract (Figure 11). 


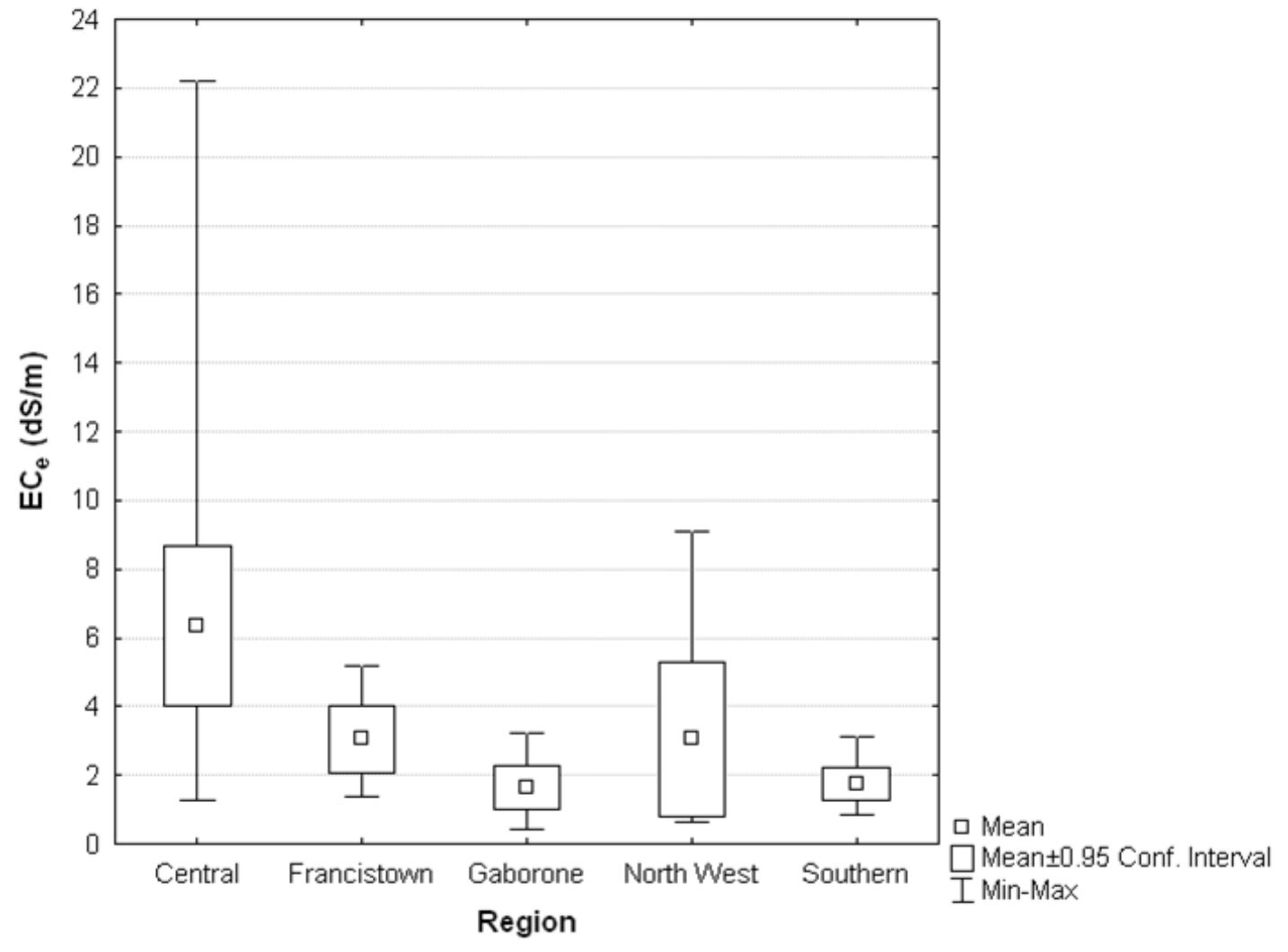

Figure 8 Average soil salinity for five regions in Botswana.

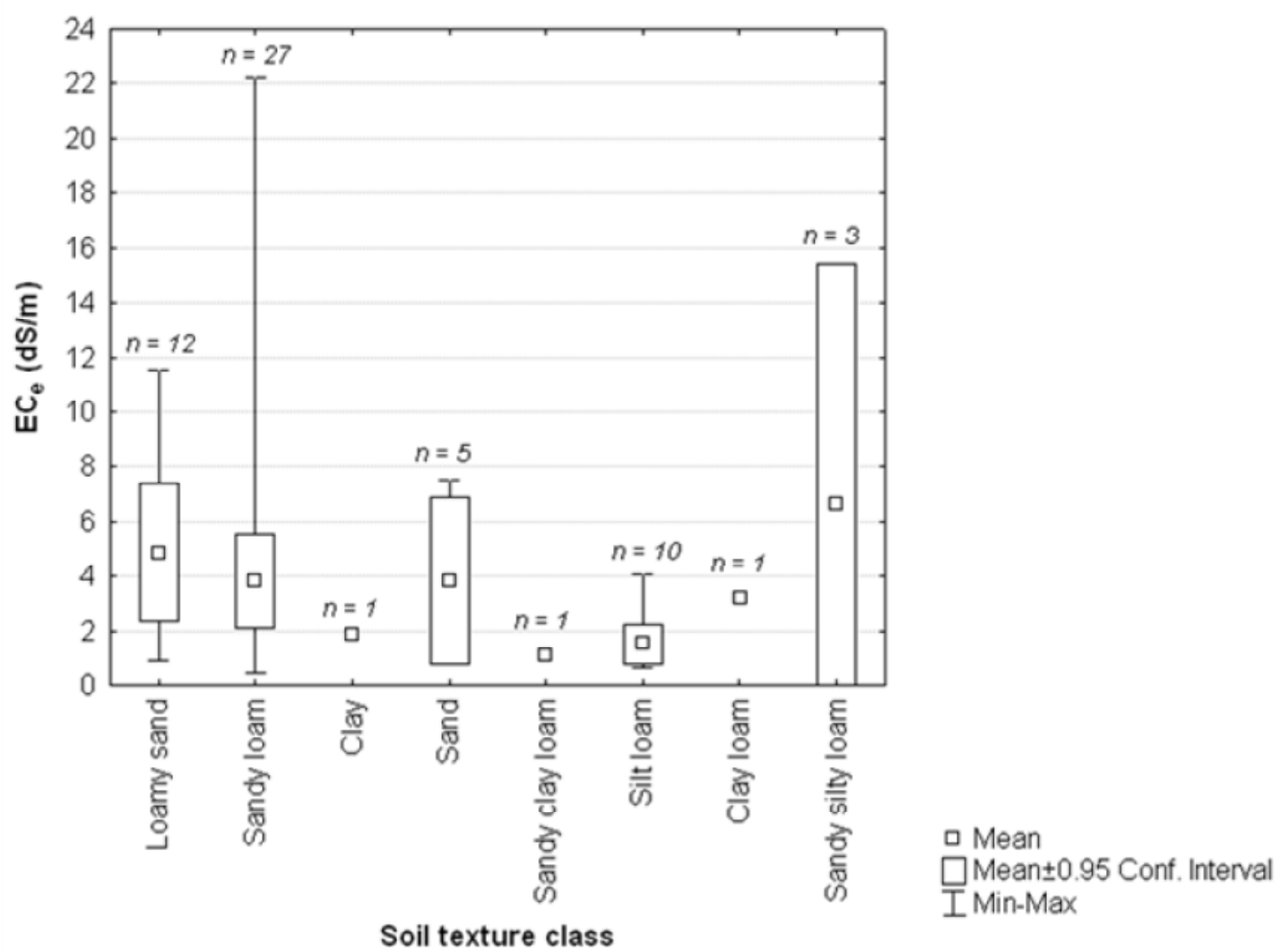

Figure 9 Average soil salinity by soil texture class. 


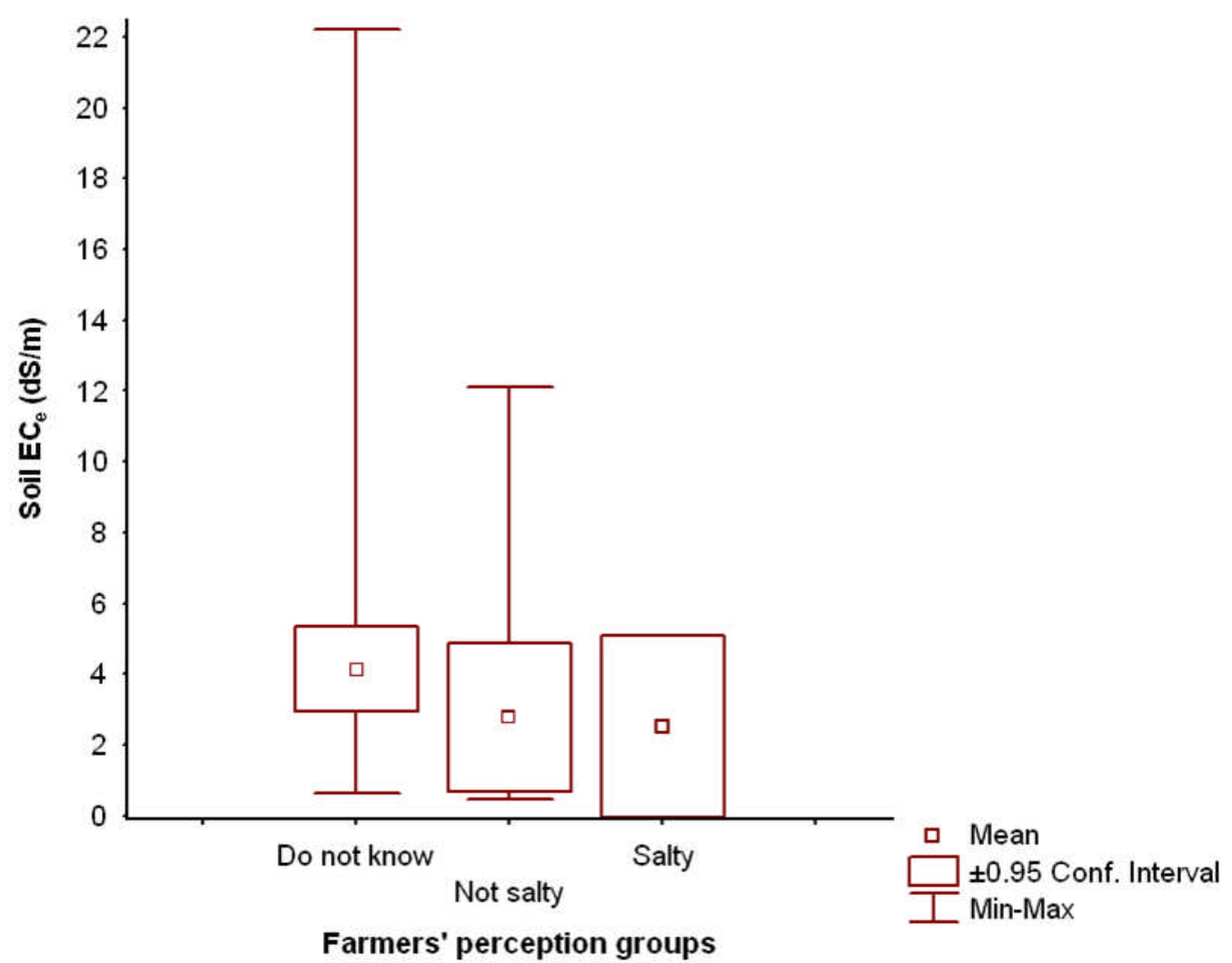

Figure 10 Actual soil salinity for the farmers' perception groups.

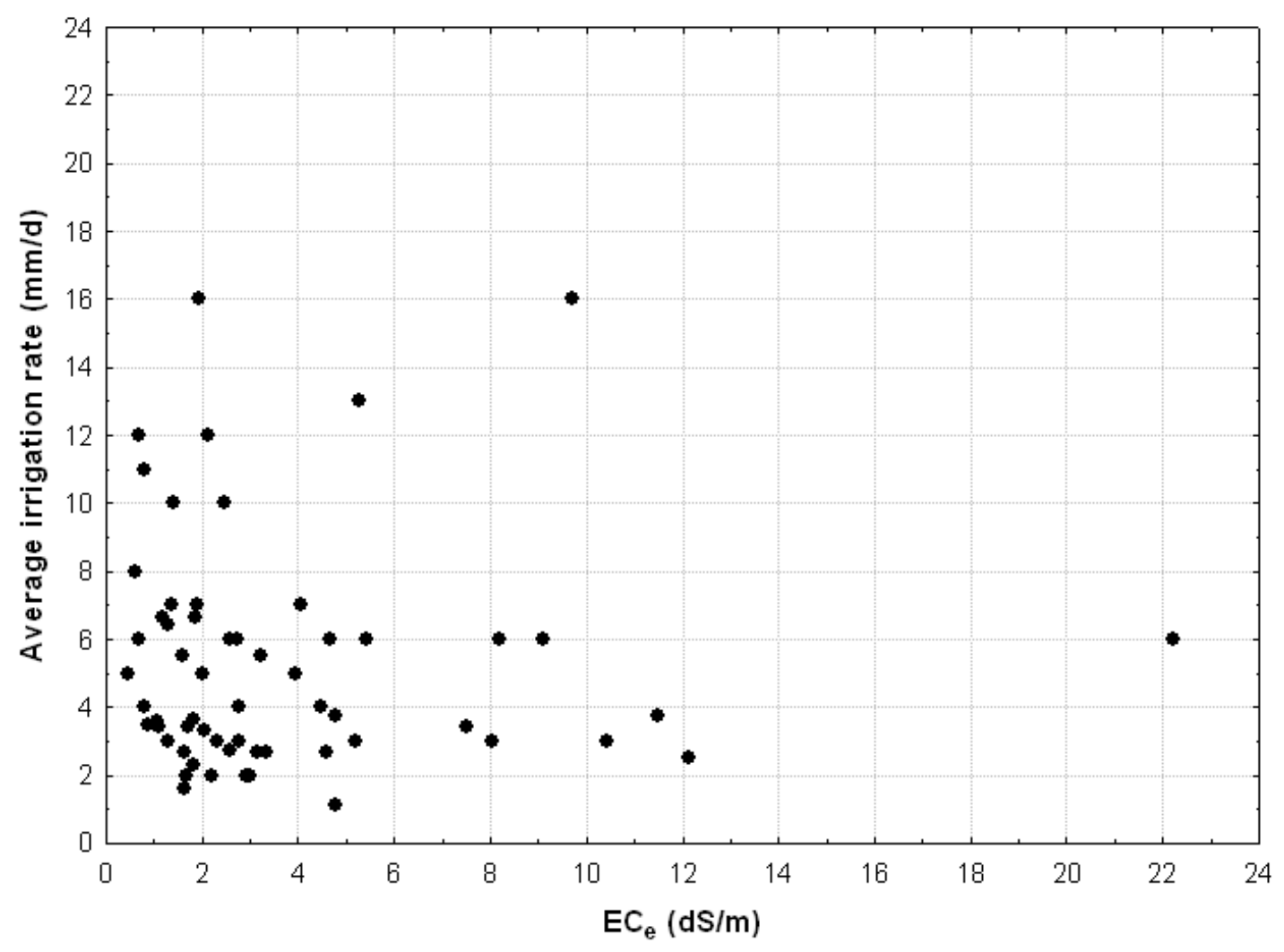

Figure 11 Relationship between average irrigation depth applied and soil salinity, $\mathrm{EC}_{\mathrm{e}}$.

$\mathrm{EC}_{\mathrm{e}}$ was significantly correlated with $\mathrm{EC}_{\mathrm{w}}(\mathrm{p}<0.001)$ and farmers using higher salinity irrigation water had higher soil salinity (Figure 12) although the predictive power of the regression is weak $\left(r^{2}=0.27\right)$. There was no significant relationship 
between the soil salinity and the number of years the farms had been cropped except in Francistown region, where the correlation was weak $(p=0.050)$, as most farmers had not been growing irrigated vegetables for many years.

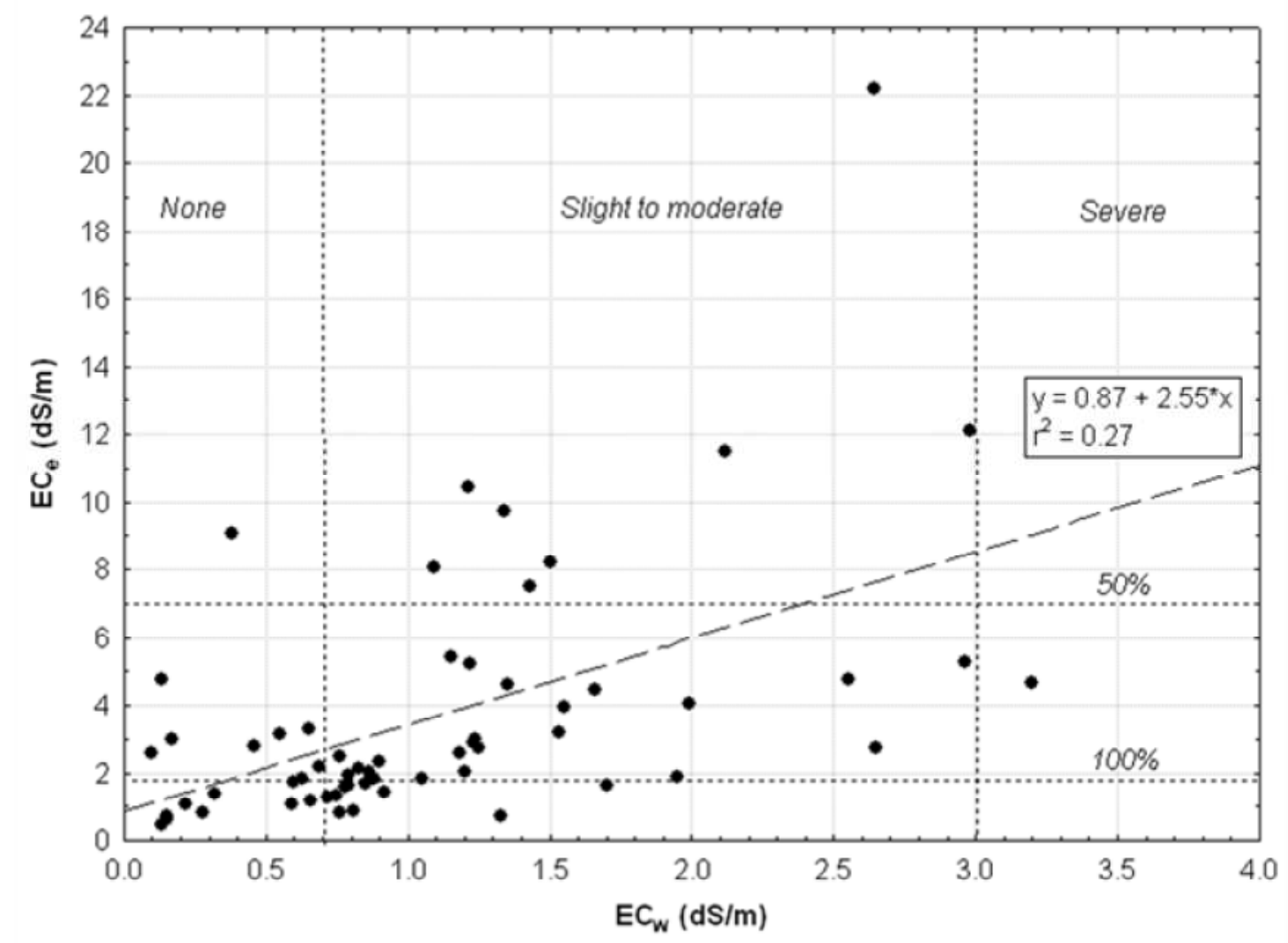

Figure 12 Relationship between electrical conductivity of the irrigation water, $\mathrm{EC}_{\mathrm{w}}$, and soil water extract, $\mathrm{EC}_{\mathrm{e}}$, showing classification for irrigation water suitability (Ayers and Westcot, 1985) and yield thresholds for soil salinity (after Maas and Grattan, 1999).

\section{Discussion}

None of the cabbage farmers surveyed used any form of scientific method to schedule their irrigation and their practices have been based on experience. Although those using sprinklers tended to put on larger applications at longer intervals than those using drip irrigation, the differences in average application rate (depth $\mathrm{x}$ interval) do not appear to be related to any of the factors studied. During the summer and winter seasons, the average crop water requirements of cabbage at full ground cover are 5.7 and $3.5 \mathrm{~mm} / \mathrm{d}$ respectively. $40 \%$ of those surveyed were applying, on average, less and 38\% more water than the winter and summer crop water requirements respectively. There was a lot of variability in the irrigation depth within each region as shown by the error bars and the average irrigation depth did not vary significantly between agricultural regions.

Sixty-eight percent of those surveyed were growing cabbage in soils with an $\mathrm{EC}_{\mathrm{e}}$ higher than the $1.8 \mathrm{dS} \mathrm{m}^{-1}$ threshold for maximum yield (Maas and Grattan, 1999). Similarly, $68 \%$ of the water sources tested fell within the "slight to moderate restriction" range of $0.7-3 \mathrm{dS} \mathrm{m}^{-1}$ (Ayers and Westcot, 1985) and the average $\mathrm{EC}_{\mathrm{w}}$ was $1.1 \mathrm{dS} \mathrm{m}^{-1}$. Only one site, of the 60 tested, fell into the "severe" category. A significant relationship was found between $\mathrm{EC}_{\mathrm{w}}$ and $\mathrm{EC}_{\mathrm{e}}$ but this did could only explain a small proportion of the variability in $\mathrm{EC}_{\mathrm{e}}$. As $\mathrm{EC}_{\mathrm{e}}$ did not differ significantly with soil type and the water table was too deep to contribute to the root zone salinity, we suggest that irrigation water was the source of salinity, but the level of 
accumulated of salt in the root zone depended on the cropping and irrigation history of the individual site.

The average irrigation rate was unrelated to irrigation water or soil salinity (Figure 13 and Figure 11) and in all the regions there were farmers who may be considered to be under- or over-irrigating in relation to the salt content of the water. Therefore, the mass of salts added to the soil in a season and the amount leached out will have differed from farm to farm. On many sites the long term sustainability of cropping may be jeopardised by poor irrigation management.

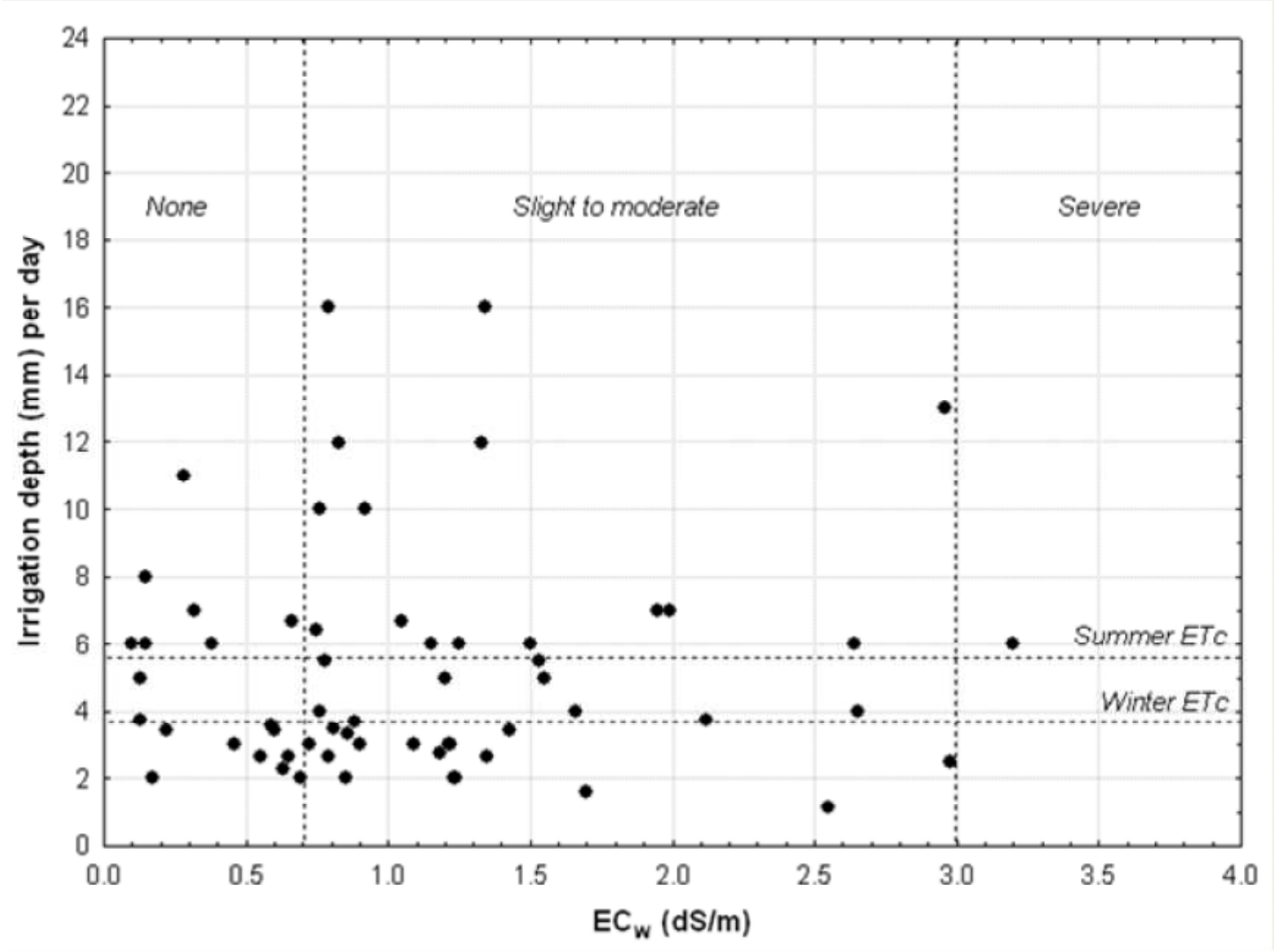

Figure 13 Relationship between average irrigation depth applied and irrigation water quality, $\mathrm{EC}_{\mathrm{e}}$, showing classification for irrigation water suitability (Ayers and Westcot, 1985) and average summer and winter crop water use, ETc.

Most of the farmers believed they knew the salinity status of their irrigation water, however, many were wrong and none were deliberately changing their irrigation practices to account for salinity. The reasons being that either they felt that there was nothing they could do or they needed advice to know what to do. Farmers who believed that they were growing cabbage on saline soil said they were doing nothing about it.

Most of the farmers surveyed did not own the land. Furthermore, the person who farms a given plot of land changes often and each farmer brings new ideas and practices. So the information in this paper is based on the irrigation management practices at the time of survey (that is the winter of 2004) and may not reflect the full irrigation history of the sites. The estimation of irrigation depths was a single measurement at the time of the interview, which may or may not have been an accurate representation of typical practice due to daily variations in wind speed or pressure or the filling of the container used for irrigation. Similarly soil sampling for the electrical conductivity tests was done only once in the season when the crops were at different growth stages. As such, the soil had received different amounts of water (and salt) for the season. However, these limitations have to be traded against 
the size of the survey which represents over $20 \%$ of the dry-season irrigated area of Botswana.

\section{Conclusions}

The survey of 60 cabbage farmers in five agricultural regions of Botswana revealed a wide range of irrigation management practices. In particular the range of average irrigation application was wide with some farmers under- and others over-irrigating. Most were using irrigation water that had a "slight to moderate" restriction on use for irrigation and two-thirds were growing cabbage in soil that was above the salinity threshold for maximum yield. In the long-term, those using the highest salinity irrigation water and applying the lowest irrigation rates may be contributing to degradation of soil resources (Tedeschi and Dell'Aquila, 2005). Most of the farmers interviewed have been growing cabbage for fewer than five years, and therefore lack the experience to understand the impact of poor irrigation management. There is clearly a need for better communication of best practices and framer training in irrigation management.

\section{Acknowledgements}

The authors would like to thank the Department of Agriculture Research, Botswana; the Extension Services of the Ministry of Agriculture, Botswana and the farmers who participated in the survey for their support. Thanks also to the reviewers of the earlier version of this paper for their constructive comments.

\section{References}

Allen, R. G., Pereira, L. S., Raes, D., Smith, M., 1998. Crop evapotranspiration Guidelines for computing crop water requirements . FAO Irrigation and Drainage Paper 56. FAO, Rome, Italy.

Ayers, R. S., Westcot, D. W., 1985. Water Quality for Agriculture. FAO Irrigation and Drainage Paper 29. FAO, Rome, Italy:

Beltrão, J., Faria, J., Miguel, G., Chaves P., Trindade, D., 2000. Cabbage yield response to salinity of trickle irrigation water, Acta Hort. 537, 641-645.

Bok, I., Madisa, M., Machacha, D., Moamogwe, M., More, K. (Eds), 2006. Manual for Vegetable Production in Botswana. Department of Agriculture Research, Gaborone, Botswana. Available at http://www.dar.gov.bw/manual1_veg_prod_botswana.pdf. Accessed 2/07/2008.

FAO and Ministry of Agriculture, 1998. Guidelines for Investigation, Design, Construction and Management of Irrigation Schemes. Gaborone, Botswana.

FAO, 1984. Agroclimatological Data: Africa 2. FAO, Rome, Italy.

FAO, 2005. Irrigation in Africa in Figures. AQUASTAT Survey 2005. Ed. K Frenken. FAO Water Report 29. FAO, Rome.

Jamil, M., Lee, C.C., Rehman, S.U., Lee, D.B., Ashraf, M., Rha, E.S., 2005. Salinity $(\mathrm{NaCl})$ tolerance of Brassica species at germination and early seedling growth. Electronic Journal of Environmental, Agricultural and Food Chemistry. 4, 970-976.

Maas, E.V., Grattan, S.R., 1999. Crop yields as affected by salinity. In Skaggs, R.W., van Schilfgaarde, J. (Eds) Agricultural drainage. Agronomy Monograph no. 38. American Society of Agronomy, Crop Science Society of America, Soil Science Society of America. Madison, USA. pp55-108. 
Maggio, A., De Pescale, S., Ruggiero, C., Barbieri, G., 2005. Physiological responses of field-grown cabbage to salinity and drought stress. European Journal of Agronomy 23, 57-67.

Tahal Consulting Engineers, 2000. National Master Plan for Agricultural Development. Volume 1, Ministry of Agriculture, Botswana.

Tedeschi, A., Dell'Aquila, R., 2005. Effects of irrigation with saline waters, at different concentrations, on soil physical and chemical characteristics. Agricultural Water Management, 77, 308-322.

U.S. Salinity Laboratory Staff, 1954. Diagnosis and Improvement of Saline and Alkali Soils. Agr. Handbook 60, USDA, Washington, D.C. 